\title{
RECENT TEACHING TECHNIQUES IN CLASSICAL DANCE
}

\author{
Purva Pandit Shreevas
}

Research Scholar

Most among the recent dancers from last decades are pursuing dance as a performer as well as a teacher. As performer we all are reaching our goals, to perform impressively, make new adaptations in our dance techniques and even maintaining the traditional style of our dance. With all of this we are able to reach students to an extent. These days students are inclined towards classical dance, parents choose classical dance over western, but the number is still low. I know this is just the beginning, still a long way to go.

Having taken education from both collegiate education systems as well as in Guru Shishya parampara I am able to get the advantages of both education system, and also have observed them closely.

We in today's times are adapting changes in almost every field; the method which was followed for our education has changed completely. All old methods are worked out and a new and convenient method which fits in today's time is launched as per the requirement. If we reverse our present life few decades back, we can see that it was subtle and people had patience in almost all things. Earlier, the subjects like dance and music were chosen with different intentions, focus was on to learn the subject in details, and with dedication. Students used to dedicate themselves to their Guru in guru shishya parampara and use to spend lot of time and energy in learning it. When students started learning dance they had enough patience and faith on guru. But today this style of education is not very much applicable.

Today as we all are so busy and need all fast returns, all things are changing. Perspective of student, environment, society etc to fulfill this need of today's time I think now its time to adopt new changes in our teaching style. As the other education systems are working on we all dancers need to do it for the benefit of dance and its future. There is a huge gap in dance education system and its accessibility. Dance education needs few changes so that it can meet today's needs. In my view the problem is that it is not available in small courses, or in introductory form, what I have observed is many children are interested to learn the dance but due to lack of time they are unable to learn it and many students don't even try it, such courses will definitely help such students maintain their interest. There is also one suggestion I want to add here, classical dance generates good society, so we all should help in adding it up, few crash courses should be introduced so that large number of students can learn and understand dance. This will help build a good audience, and also sensitive society, which is one of the major problems faced today.

Classical dance seminars should be organized more and more so that with interaction new ideas and concepts can be worked out. As it is a performing arts students should get regular opportunity to perform which will also encourage them to learn it in details. 


\section{INTERNATIONAL JOURNAL Of RESEARCH -GRANTHAALAYAH \\ A knowledge Repository} Art

There are many steps taken to encourage classical dance but still a great scope of improvement is there. Government should also introduce some promotional and developmental schemes for dance and it should get the same respect as other main stream subjects. I am sure that these things will add on to the development of dance, and help dance grow more and reach maximum people. Let us all join hands and work for progress of dance as we all are able to do it today with the help of MLB College, and Suchitra ma'am. I thank one and all for giving your precious time in reading and listening to this article of mine. 